\title{
8 頭頚部癌患者の踟床経過と免疫学的動態について
}

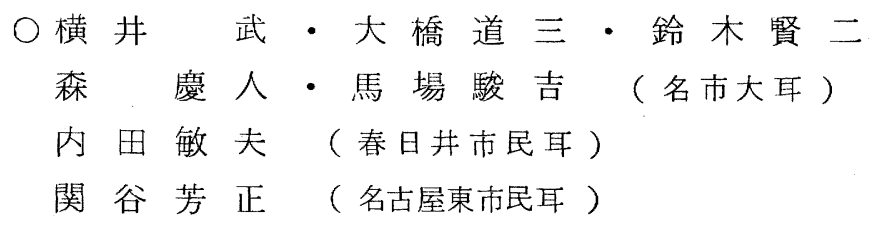

我々は頭頸部癌患者の免疫動態を $\mathrm{T}$ - cell、 $\mathrm{P}$ P D、数種 $\alpha-g l$ obul in およびT $\gamma$ などを指標と して測定し、担癌患者で注 $\alpha_{1} \mathrm{AG} 、 \alpha_{1} \mathrm{AT} 、 \mathrm{CP}$ の 增加、 $\alpha_{2} \mathrm{HS}$ の減少傾向、T $\gamma$ の增加すること をこれ迄に報告してきた。今回は放射線療法、免 疫療法を行ない 6 ケ月以上経過を観察しえた頭頸 部癌患者について臨休経過とともにこれらの指標 がどの様な変動を示すかを検討した結果を報告し た。先ず一次治療として放射線治療を行ない 6 力 月間再発をみないものをwell control 群とし、制 御出来なかったり 6 力月以内に再発をみたものを poor control 群として比較した。 $\alpha_{1} \mathrm{AG}$ では well control 群は照射終了1 カ月後より下降傾 向がみられるのに対して poor control 群では 3 カ月後位から上昇傾向がみられた。 $\alpha_{1} \mathrm{AT}$ でも 同様に well control 群では正常域を維持している が poor control 群で治療後一旦正常域に近づ くが漸次，上昇傾向を示した。これに対し $\alpha_{2} \mathrm{HST゙}$ は we11 control 群では照射終了後より上昇傾向 にあり、 poor control 群では終了媵一旦上昇傾 向がみられたが 3 カ月後より下降傾向が認められ た。Trはwell control群では照射終了1カ月後 より下降し正常域を維持する様になるが poor control 群では上昇傾向がみられた。この様に $\alpha_{1}$ $\mathrm{AG} 、 \alpha_{1} \mathrm{AT} 、 \alpha_{2} \mathrm{HS} 、 \mathrm{~T} \gamma$ は臨床経過をある程度 反映した結果を示したのではないかと考えている。 次にこれらIRAとTrがはたして parallel に変 動するものかどうかをwell control 群を対象に 比較してみた。 $\alpha_{1} \mathrm{AG} 、 \alpha_{1} \mathrm{AT}$ ともにTrとほぼ parallel に変動を示した。一方 $\alpha_{2} \mathrm{HS}$ では照射 後より上昇傾向にあり、 $\mathrm{T} \gamma$ は 1 力月後より下降 し両者間には逆相㮳の関係がある様に考えられた。
これらの傾向は poor control 群においても well control 群とほぼ同様の関係がみられた。

次に免疫療によってこれら parameter が比較 的 parallel な動きを示したものと、示さなかっ たものの代表例を供覧した。しかし今回は症例数 が少ないため有意差検定は行なっていない。

質問 藤井 ( 東海大耳)

我々の場合、経過不良例では $\mathrm{T} \gamma$ は下り、良好 例では上昇する。良好例の場合、治療内容として 放射線照射が多くの割合をしめている。何か治療 内容上の特徵はあるかどうか。

回答

横井 (名市大耳鼻咽喉科)

$\mathrm{T} \gamma$ は我々の検討では経過不良例で増加し、経 過良好例で低下を示した。 先生のデーターと逆との事ですが、特別な治療方 法沈とっていません。

放射線療法と免疫療法 (OK 4 32、PSK)が主体。 